\title{
The Role of Fishermen's Wife in Increasing Family Income
}

\section{Ecces: \\ Economics Social and Development Studies}

\author{
Wilda Fesanrey ${ }^{1}$ \\ Samsia Umasugi ${ }^{2}$ \\ M Chairul Basrun Umanailo ${ }^{3}$ \\ 1,2 Faculty of Fisheries and Marine Sciences, Iqra Buru University, Indonesia \\ ${ }^{3}$ Faculty of Agriculture and Forestry, Iqra Buru University, Indonesia \\ E-mail: wildafesanrey@gmail.com ${ }^{1}$, cia umasugi@gmail.com, chairulbasrun@gmail.com
}

(Article history) Received: 2020-10-06, Revised: 2020-11-29, Accepted:2020-12-03,

Available online 2020-12-8, DOI: 10.24252/ecc.v7i1.13382

http://journal.uin-alauddin.ac.id/index.php/ecc/index

\section{Abstract: The Role of Fishermen's Wife in Increasing Family Income}

The uncertainty of the income that the head of the fisherman's household in Namlea Village encourages his wife to work to meet family needs. The role of the fishermen's wife is needed because it affects the level of family income. This is what encourages researchers to conduct research with the aim of knowing how the role of fishermen's wives in increasing family income in Namlea Village, Buru Regency. The method used in this research is a survey method, which is an investigation that obtains facts from the existing symptoms of the role of fishermen's wives in Namlea Village, Namlea District, Buru Regency and analyzed by descriptive method. Sampling in this study using a purposive sampling method. This type of research is descriptive qualitative. Respondents taken in this study amounted to 18 people or $25 \%$ of the total population of 72 fishermen's wives. The domestic role of women, which are all activities carried out by fishermen's wives in maintaining fishermen's households, which consists of jobs such as cooking, washing, ironing, cleaning the house, and childcare are priceless. The public role of women is all the activities of fishermen's wives that generate income outside of their homes. Fishermen's wives are required to play a role in making a living by being involved in earning a living. The work that is done by the fishermen's wife is like selling fresh (raw) fish and processed fish (smoked fish). The results of this study indicate that 18 fishermen wife respondents show a contribution or proportion that affects the total income of the fishermen's family with the criteria classified as moderate, which means that it is quite influential in increasing family income and can meet family needs. This research can assist local governments in formulating policies related to improving fishermen's welfare through the active role of family members.

Key Word: Family; Fishermen's Wife; Income; Role. 
Wilda, Samsia, Chairul, The Role of Fishermen's Wife in Increasing Family Income.

\section{INTRODUCTION}

Buru Regency is one of the regencies located in Maluku Province. Buru Regency has abundant natural resources both from land and water areas such as fisheries and agriculture. This abundant natural resource has not been able to make the fishing communities in Buru Regency, especially in Namlea Village, Namlea District, live in prosperous conditions.

Based on the results of observations in the field of welfare experienced by fishermen, it is still minimal, which is indicated by the backwardness of education, underdevelopment in fisheries processing, so that it has an impact on the low income received by fishermen. The level of education experienced by fishermen's families in Namlea Village is still far from desired, this is because the income earned by the head of the family is not enough to continue their children to higher education levels.

The processing of fishery products carried out by fishermen households in Namlea Village is still not very good, because knowledge about fishery product processing is still very minimal.

According to Zuraidah et.al (2018) that human resources in the fisheries sector are generally still weak, this condition is illustrated by the structure of the workforce and low levels of education. The low level of education of fishermen and fish farmers tends to hamper the process of transferring technology and skills which has an impact on their management capacity and business scale.

The resources in the fisheries sector in Namlea Village are one of the important resources for the livelihood of fishermen and have the potential to be used as the prime mover of the economy. This is based on the fact that first, Namlea Village has considerable fishery resources, both in terms of quantity and diversity. Second, there is a linkage of other sectors to the fisheries sector.

Along with the times and the fulfillment of the living needs of fishermen in Namlea Village is always increasing, the head of the fishing family must be able to meet the everincreasing economic needs. Starting from the fulfillment of basic household costs, children's education costs, family health costs, and also other costs. So that in order to meet these needs, the income earned by the head of the family must be more or increase.

The uncertainty of the income that the head of the family receives as a fisherman encourages other household members such as his wife and children to work in order to fulfill household needs. Fishermen's wives have an important role in increasing household income. 
Artini and Puspaningsih explained that working women are to help the family economy (Artini and Puspaningsih, 2011). Derman said that the presence of working women will certainly be able to raise family welfare because they get additional income from their work. This phenomenon shows that the role of women as housewives and as seekers for additional income can run well because of the participation of women in helping improve family welfare (Listiyandra et al., 2016).

Fishermen households in Namlea Village have special characteristics such as the use of coastal areas and oceans (common property) as a factor of production, the uncertainty of income, working hours that must follow the circumstances (Sumitro et al., 2020). Uncertain catches coupled with bad climatic conditions cause fishermen to sometimes not bring their catch, to get around fulfilling family needs the role of fishermen's wives. according to Mugni (2006) that women do not only act as housewives but also carry out productive activities to increase income.

The role of women from low-income households tends to spend more time on productive activities compared to the work of women from high-income households (Husain et al., 2016).

Based on the results of research, the condition of the fishermen in Namlea Village is still living in a less prosperous level. Most of them are still unable to meet the needs of their families, especially in education and other secondary needs, their primary needs are still not being fulfilled optimally. The income they generate from fishing in the sea is not able to meet the needs of the family. So that many of their children cannot continue their education to a higher level, namely undergraduate. This condition causes their other family members to intervene in meeting primary and secondary needs, namely by working as processors of fishery products, sellers of raw/fresh fish, laborers, and others. The other members consist of fishermen's wives and children.

The role of fishermen's wives is needed to form the husband's income so that the family's needs are met (Zainudin et al., 2019). So far, research on this matter in Namlea Village has never been carried out, therefore research has been carried out related to the role of fishermen's wives in increasing family income.

This research was conducted to determine the role of fishermen's wives as housewives in supporting family income. Fishermen's wives have a very important role in increasing their family's income because one of the fishermen's family members, namely the 
Wilda, Samsia, Chairul, The Role of Fishermen's Wife in Increasing Family Income.

wife, has a significant role in increasing their family's income. In general, fishermen's wives work in the fisheries sector where the work is informal (Kanto et al., 2020). In general, fishermen's wives work in the fisheries sector both as marketers of catches and processing, but not a few of them work outside the fisheries sector, such as becoming entrepreneurs or laborers. This situation also applies to fishermen families in Namlea Village, Namlea District, Buru Regency.

Several previous studies on the role of the wife on family income. Zen (2009), said that there are various types of work for fisherwomen and their contribution is very important in meeting the needs of fishermen households in the village districts Pasie nan Tigo. Soeyono et.al (2013), said that the amount of work time spent, the number of family dependents, the level of education, and the length of work had a positive effect on the income of women laborers at PT Gading Mas Indonesian Tobacco. Salamah (2005), said that the role of women in the household economy of coastal fishermen is relatively large.

\section{THEORETICAL REVIEW}

In general, people still think that the duty of women as a wife as well as a mother is to first take care of the household as well as possible. It seems a little strange if there are women who don't understand housekeeping and they just sit idly by, even now the mothers at home never stay still and are always active. In managing fishermen's households, it is possible to have the important role of wives, especially in managing household finances (Stevens et al., 2015). The wife also plays a role in the decision-making process in the household considering that the husbands are busy earning a living. The wife has a dual role, namely as the breadwinner when the husband's income is not sufficient to meet the needs of their household.

According to Kusnadi (2009) that "the economic role of coastal women is quite strong and dominates, both at the household and community levels. At household level, coastal women become "one of the economic pillars" of the household, in line with their husbands. " The functional relationship between husband and wife in meeting the economic needs of the household is complementary. Coastal women are not just "complementing or helping". Meeting household economic needs, but also determines the availability of economic resources for household needs.

According to Mu'adi et al (2020) that there are several things that cause the wife to play a role in the family economy, namely the wife works because of economic factors, in 
addition to the welfare of the family, the wife also gets support from the husband because her income cannot meet family needs, cultural factors, and social factors.

The theory of role and function according to Talcott Parsons (Ritzer et al., 2008) that the combination of value orientation patterns is obtained at a very important level, must be a function of the fundamental role structure and the dominant value of the social system of fishermen families that have a low economic level or whose income is still insufficient to meet the needs of their families. Based on a quote from Talcott Parsons' opinion, the role of a wife is to help increase the economic needs of the family as an effort to increase household income in the family. Besides that, fundamentally it can be said that the wife also functions as a mother who manages the needs of her children, and as a wife can serve the needs of the husband which is one form of creating household harmony.

Merton's theory focuses on the objective consequences of individuals in behavior. The object consequences of the individual in this behavior are functional and some are dysfunctional (Payne, 2013). According to Merton, functionalists initially limited themselves to studying society as a whole, but Merton explained that it can also be applied to organizations, institutions, and groups. According to Merton, functionalists initially limited themselves to studying society as a whole, but Merton explained that it can also be applied to organizations, institutions, and groups.

Merton suggested manifest and latent functions (Ciołek et al., 2018) The manifest function is the desired function, latent is undesirable, in the existing structure, things that are irrelevant, as well as latent dysfunctionality, are affected functionally and dysfunctionally. The manifest function is the desired function, latent is undesirable, in the existing structure, things that are irrelevant, as well as latent dysfunctionality, are affected functionally and dysfunctionally.

Goode (1992) The family is the smallest unit in society, as a social institution that is very old and the family can only function properly if it gets community support. Family and society have a functional relationship that is reciprocal. Basically, in the family, there are several roles that must be carried out by each individual family member in order to create the desired order. The role describes a set of interpersonal behaviors, traits, activities, which relate to individuals in certain positions and situations. The role of individuals in the family is based on the expectations and behavior patterns of the family, group, and society. 
Wilda, Samsia, Chairul, The Role of Fishermen's Wife in Increasing Family Income.

Helmi et al ( 2012), A person has a role, both at work and outside. Each role requires different behavior (Prestes-Carneiro et al., 2016). In the work environment itself, an employee may have more than one role, an employee may be a subordinate, provider, union member, and representative on the workplace safety committee.

According to Hubies (2001) the role of women can be carried out from the perspective of their position in dealing with indirect productive work (domestic) and direct productive work (public), namely as follows: (a) The role of tradition places women in reproductive functions (taking care of the household, giving birth and caring for children, and protecting their husbands). His life is $100 \%$ for the family. The division of labor is very clear, namely women at home and men outside the home. (b) The transitional role models the role of tradition as being more prominent than other roles. The division of tasks follows gender aspirations, but the existence of maintaining harmony and household affairs remain the responsibility of women. (c) Dwiperan positions women in the life of two worlds, namely placing the domestic and public roles in equal importance. Husband's moral support triggers toughness or vice versa husband's reluctance will trigger unrest or even cause open or hidden conflicts. (d) An egalitarian role takes women's time and attention for outside activities. Moral support and a level of concern for men are essential to avoid conflicts of interest, separating, and distributing roles. If not, what happens is that each of them will argue with each other to find justification or create an uncomfortable family life atmosphere. e) Contemporary roles are the impact of women's choice to be independent in solitude. The number is not large, but the clash of people dominating women who do not really care about women's interests may increase the population.

The most important roles and positions for women in the family areas wives and mothers who organize the running of the household and look after children. The wife's job is expected to be able to cook, sew, maintain the house, and give birth. In connection with this task, ideally, the wife's place is at home, the wife plays a role in the domestic sector.

In determining the wife's role as a housewife, it means that the wife's place and obligations are in the domestic sector. This also means that inside the house, the private sector, without having a formal position in society. In society, the official position of a woman as a wife is the wife of her husband. All of these situations tend to reinforce stereotypes such as a wife (obliged) to be a wise and pleasant mother, good at maintaining family honor, having to provide peace to her husband, being able to organize family life, and creating a happy atmosphere in the family. 
The opinion of Sasongko (2009) emphasizes the concept of partnership and harmony in the relationship between women and men. This view does not conflict between women and men, because both of them must work together in partnership and harmony in the life of the family, society, nation, and state.

Moore's et. al (2002) opinion mentioning that women's daily lives are different in one context of multiple burdens. The burden of providing unpaid care in services in domestic work, as well as the burden of providing economic viability through wage labor, provide the norm for women. Based on this opinion, it means that the double burden of a fisherman's wife becomes dominant in helping the family's economy so that the daily needs of life can be fulfilled as one of the factors in increasing the economic income of fishermen's families.

The increase in women's participation in economic activities is due to: first, changes in people's views and attitudes about the importance of education for women and men, and the increasing awareness of the need for women to participate in development. Second, there is a woman's willingness to be independent in the economic field, namely trying to pay for her daily needs and perhaps also the necessities of life of her dependents with their own income. Another possibility that has led to an increase in women's participation in the workforce is the expansion of employment opportunities that can absorb female workers, for example, the emergence of handicrafts and light industry.

Fishermen's wives have the potential to contribute to household income, especially fishermen households whose income is not sufficient. In fishermen's households, household members, especially wives, enter the labor market to increase the household income that is felt to be insufficient. The income of fishermen's wife workers in the clothing industry has a significant contribution to the increasing family income.

According to Wawansyah et. al., (2012) that the income level of the head of the family has an effect on household welfare, but the welfare in the household does not depend on the figure of the head of the family but is influenced by other household members as a member of the family, fishermen's wives have a significant share in increasing income and realizing family welfare.

Boediono (2002) explains the belief of someone who is trusted by several factors, including those that determine the number of production factors that are owned by the source, the results of this year's savings and inheritance or offer, the price per unit of each factor of production, this price is determined by supply and demand in the market for 
Wilda, Samsia, Chairul, The Role of Fishermen's Wife in Increasing Family Income.

factors of production, the result of activities of family members as a side job. According to Sari et al., (2013) The income of fishing communities depends on the utilization of the potential fishery resources in the oceans. The income of fishing communities will directly or indirectly affect their quality of life, because the income from sailing is the main or even the only source of income for them so that the size of the income will greatly affect their lives, especially their ability to manage the environment. where they live.

In the gender language used to describe nature, and the imaginative language used to describe women. Some discourses link women specifically to the environment, because of their traditional social roles as caregivers and caregivers. Shiva ( 1988 ) Ecofemists who follow this line of thought believe that this relationship is illustrated by the coherence of socially labeled values associated with 'femininity', such as nurturing what is visible, both in the context of women and in nature. Shiva ( 1988 ) said that women have a special connection to the environment, through their daily interactions and this connection has been neglected. She said that women in subsistence economies that generate "wealth in partnership with nature, have become experts in their own right to holistic and ecological knowledge of natural processes". She emphasizes that these alternative modes of knowing, which are oriented towards social benefits and the need for sustenance, are not recognized by the reductionist capitalist paradigm, because it fails to understand the interconnectedness of nature, or the relationship between life, work, and women's relationships. Because capitalism is more about knowledge for the creation of as much wealth as possible.

The decline in fishermen's income has an effect on the household economy. The fishermen's wives eventually became victims. They sought debt and pawned goods when she and her husband did not go to sea or only got a few catches. Their mainstay job is only fishing while other skills cannot. Other fishermen's wives' jobs are seeking loans or spending money if they don't have money, especially when there is little or no seafood, both for daily food needs, the provision of money for the main production costs, namely boat repairs, and tools catch and also related to the provision of supplies during fishing or operational costs. All of these needs are obtained by the wife from the nearest shop that is usually her customer. The method of payment is after the husband returns from carrying out his job and after the fish he catches are sold. 


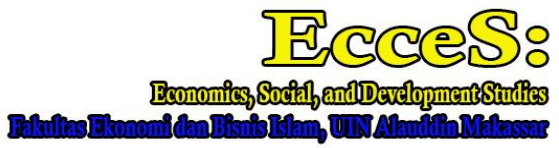

Volume 7 Number 2 Ed. December 2020 : page 155-176 p-ISSN: $2407-6635$ e-ISSN : 2580-5570

\section{METHODS}

In this study, the method used is descriptive with data collected and analyzed using descriptive methods, namely the presentation of the analysis through interpretation accompanied by rational interpretation of the factors in the field, namely: Household characteristics, the wife's reasons for working, and the problems faced were analyzed using descriptive qualitative methods. The working hour outpour is calculated by finding the working time unit hours per day and days per month; The income contribution of fishermen's wives to total household income is analyzed by tabulation without statistical tests by calculating the amount of money generated or obtained from economic activity (making processed fishery products) and the total household income using the formula (Widodo, 2012).

The population is the entire fishermen's wife, while to determine the sample using purposive sampling technique, is a sampling technique with certain considerations (Zuraidah, 2018). The reason for using this technique is because the author refers to people who are related to research problems, thus the research sample is determined as many as 18 fishermen's wives who work to help improve their family's economy, with criteria based on the husband's job as fishermen or full fish farmers are people who all the time its work is used to carry out fishing or fish maintenance operations. The total number of respondents is $25 \%$ of the total population according to Arikunto (2008). The number of large subjects can be taken between $10-15 \%$ or $20-25 \%$ of the total population. A total of 18 people from fishermen's wives were made different responses and selected by purposive sampling according to the objectives.

Collecting data in this study using direct observation. The data collected includes primary data and secondary data. Primary data is data that is collected by an individual/organization directly through its object (Supranto, 2003). Meanwhile, secondary data were obtained from agencies related to the research to be carried out as well as related literature, which were obtained from various written sources.

In the process of validating the truth data obtained, the writer uses triangulation techniques. Triangulation used is a triangulation of sources and methods. Source triangulation is done by comparing data from several sources. Meanwhile, method triangulation is used when analyzing data by comparing data from observations, interviews, and related documentation. 
Wilda, Samsia, Chairul, The Role of Fishermen's Wife in Increasing Family Income.

In the data analysis stage, there are three processes: data reduction, data presentation and conclusion drawing. The three stages are very synergistic. First, data reduction, which is the stage of sorting and transforming some of the data that emerged during the study. Simply put, data reduction is a stage of analysis that seeks to direct, sharpen, and organize data in order to obtain a result.

Then the second stage is the presentation of data which is a collection of information composed of data that has been obtained and allows leading to the process of drawing conclusions. At this stage, the author's goal is to describe the situation and core problems so that they can be understood properly.

The third stage is drawing conclusions, namely the final stage in the data analysis process. This stage is the result of sorting the data, presenting the data as a representation of the situation, then drawing the results and conclusions. The purpose of this stage is to find out and provide overall data results related to the topic of writing that the author has done.

\section{RESULTS AND DISCUSSION}

The reason fishermen's wives in Namlea Village work to increase family income are due to (a) the husband's income is not sufficient, namely because women do not only act as housewives but also carry out productive activities to increase income. The husband's lack of income in meeting household needs causes fishermen's wives to take the initiative themselves in managing the fishermen's catch as an effort to increase income. As from the results of interviews obtained from several respondents who are fishermen's wives as research objects, it is revealed that one of the economic difficulties in their family is the husband's income which is uncertain, and (b) the high demand for living costs where basically households need money to meet their daily needs. These costs are obtained from the income of all family members. Income and expenses in a household must be different. Income can be used for consumption and savings expenses. Expenditures for consumption are channeled to expenditure on food, clothing, housing, fuel and so on. In economics, consumption is defined as all the use of goods and services made by humans to meet their daily needs (Rosyidi, 2000). Consumption expenditure is carried out with the intention of maintaining a standard of living. At low levels of income, consumption expenditure is spent primarily on basic necessities to meet physical needs. Food consumption is the most important because food for fishermen's wives in Namlea Village is the main ingredient for sustaining their life. However, there are still many other consumer goods that can be 
considered as necessities for household life. Diversity depends on the level of household income. Different levels of income lead to different levels of consumption.

Angela et. al, (2015) that Projects and other endeavors have emphasized the important role of women in fisheries, but especially from the perspective of their contribution to processing and marketing. The government, projects and policies have reinforced the idea that the main position and role of women is in the manufacturing sector. Over the years, these efforts have resulted in women benefiting from training in processing and marketing, through grants and credit for processing equipment, and capital funds to buy fish and pay for transportation.

From the research results obtained from all respondents stated that the reason they work is a physiological boost to help their husbands earn a living, because the income generated by their husbands cannot meet the necessities of life so that the wives are required to work for a living so that they can help make a little more of their living they. Another reason that makes these fisherwomen work is that the income from their husbands as fishermen is very uncertain because the results obtained are in accordance with the number of catches they get, when the fishing season is good, their income will be high automatically meanwhile when the fishing season is not good, their income will be low or decreased, and if the wind is strong, many fishermen do not carry out fishing operations, they prefer to stay at home, clean or repair damaged nets at home. This makes the wives have to prepare to prepare savings in case there are sudden expenses while the husbands have not given money for daily needs so that the way out of this is that the wives are required to work so that they have savings at home.

Table 1. Age Distribution of Fishermen's Wives (Respondents)

\begin{tabular}{cc}
\multicolumn{2}{c}{ in Namlea Village } \\
\hline $\begin{array}{c}\text { Age Range } \\
\text { (Year) }\end{array}$ & Number of Respondents \\
\hline $24-45$ & 10 \\
$46-64$ & 4 \\
$>64$ & 4 \\
Total & 18 \\
\hline
\end{tabular}

Source: Primary data after processing, 2020

Age greatly affects the productivity of the work a person will do. Demographic analysis, the age structure of the population can be divided into three groups, namely : (a) young age group, under 15 years; (b) productive age group, aged 15 - 64 years; and (c) old age group, aged 65 years and over (Sukmaningrum and Imron, 2017). Fishermen's wives in 
Wilda, Samsia, Chairul, The Role of Fishermen's Wife in Increasing Family Income.

Namlea Village generally have a productive age ranging from 24 years - 64 years with a total of 14 people and those who are no longer productive aged $>64$ years are 4 people.

Education is one of the determining factors that can determine the development and livelihoods of the community. With the high level of education of a society, it will change the mindset and be able to keep up with changes in technological advances that continue to develop so as to produce a competitive society and improve the welfare of society. A person's age is one of the internal characteristics of an individual that affects a person's ability to learn, understand, accept, and adopt an innovation.

According to Bawolye et al., (2019) that the level of education is a stage of education that is determined based on the level of development of students, the goals to be achieved and the willingness to be developed. The level of education on changes in attitudes and behavior in people's lives. A higher level of education will make it easier for a person or community to absorb information and implement it in daily behavior and lifestyle, especially in terms of fisheries activities. Formal education forms value for someone, especially in accepting new things.

The previous research related to the findings of this research is Hutapea et. al., (2012) about the role of fisherwomen (fishermen's wives) gill nets in increasing family income in Bejalen Village, Rawa Pening Waters, Nambarawa District, Semarang Regency states that the higher the level of education, the decisions taken will be more rational and will lead to an increase in family economic welfare. Whereas those who oppose are Lamia, (2013) in a study of the factors that affect the income of fishermen in Tumpaan District, South Minahasa Regency, the results show that capital, labor, experience have a significant effect on fishermen's income, while the length of education has no effect on fishermen's income.

Table 2. Fishermen's Wife Education (Respondent) in Namlea Village

\begin{tabular}{cc}
\hline Description & Respondent (Person) \\
\hline Not Graduate SD & - \\
Graduate SD & 5 \\
Graduate SLTP & 4 \\
Graduate SLTA & 9 \\
Total & 18
\end{tabular}

Source: Primary data after processing, 2020

Based on the table above, it is known that the level of education of fishermen's wives (respondents) has the greatest number of elementary school graduates with a total of 5 people, There are 4 people who graduated from SLTP and the highest level of education (SLTA) is 9 people. Where the low education of fishermen's wives is an inhibiting factor in one's progress both in knowledge, skills and also affects one's mindset in accepting better changes. 
Education and training are likely to be important in every step of the way to improve women's status in fisheries, so the availability of fisheries / maritime training and education is questionable, as is their availability for women. It was revealed that some vocational or specialized training is available in most of the member countries and is universally (where answers are accepted) available for women. Thus, in principle at least the potential availability of training and education does not appear to be an obstacle.

In general, the number of family dependents is the family member who is the responsibility of the head of the household consisting of wife, children and other family members including the head of the family himself. The size of the family dependents will directly affect expenses. On the other hand, the amount of family responsibility is a heavy burden for fishermen in dealing with it. Large but low productive families will lead respondents to a weaker position, especially in efforts to build capital for the future.

The extent to which the family dependency burden of each respondent affects the level of their needs and welfare, the more dependents the family has, the more household needs must be met. If the income from work is not able to meet the needs, this will have an impact on welfare problems in the family.

Table 3. Dependents of Fishermen's Wife (Respondent) in Namlea Village

\begin{tabular}{cc}
\hline Dependents of the Family & Respondent (Person) \\
\hline $2-4$ & 11 \\
$5-7$ & 7 \\
Total & 18 \\
\hline Source: Primary data after processing, 2020
\end{tabular}

The average number of fishermen's wife's family dependents is 5-7, around 7 people and the number of family dependents is $2-4$, around 11 people. Where a large number of family dependents in one house causes a large number of household expenses to meet their daily needs, including the cost of children's education. A large number of family dependents is due to the high birth rate of coastal communities. This is closely related to the low level of education they have, where the views of many children are still developing.

The results of the study regarding the marital status of fishermen's wives in Namlea Village were married. The average wife of a respondent fisherman is married at a young age ranging from 17-20 years. The totality of an individual's abilities is essentially composed of two factors, namely intellectual abilities and physical abilities as well as interests which can cause someone to be active in doing something that has attracted his interest. Therefore, a 
Wilda, Samsia, Chairul, The Role of Fishermen's Wife in Increasing Family Income.

wife's interests and abilities affect the fishermen's wife's role in working or entrepreneurship in order to increase family income. The findings of this study are in accordance with the results of Manalu's research, which states that ability is the capacity of an individual to perform various tasks in a job where the overall abilities of an individual are very dependent on their physical abilities and intellectual abilities. So that the abilities possessed by fishermen's wives will affect the role of these wives in increasing family income through entrepreneurship (Sumrin et al., 2015).

The results of research in Namlea Village show that the interest or desire of women or fishermen's wives to be financially independent causes them to do work by earning income which will later be used to finance or buy the necessities they want. Thus, this interest encourages the wife's role to work in accordance with her abilities to meet the daily needs of the family.

The type of work done by fishermen's wives cannot be separated from the potential and condition of the resources around them, so it is not surprising that the type of work performed tends to be in the fisheries sector (Firdaus and Rahadian, 2016). This is in line with what Nawawi expressed, that the life of coastal communities, especially fishermen, is very dependent on the environmental conditions of the resource (Matera, 2014).

Table 4. Type of Occupation of Fishermen's Wife (Respondent) in Namlea Village

\begin{tabular}{lc}
\hline \multicolumn{1}{c}{ Type Of Work } & Respondent (Person) \\
\hline Processed Fish seller (smoked fish) & 5 \\
Raw Fish Seller & 13 \\
Total & 18 \\
\hline \multicolumn{2}{c}{ Source: Primary data after processing, 2020}
\end{tabular}

The types of work done by fishermen's wives in processing fishery products (Smoked Fish) totaled 5 people and the most jobs done by fishermen's wives as raw fish sellers were 13 people. This is because they live in a coastal area which makes it easy for them to find fish and fish is also used as raw material which is processed into smoked fish and will be sold to the Namlea market.

Work experience is one of the factors that determine a person's success in doing business. The more business experience a person has, the more accustomed and experienced he will be in running the business so that in the end the business that is carried out will run well.

Experience is also important in the success of a business. The experience will make it easier for gill net fisherwomen to deal with problems in their business. The following shows the distribution data of fishermen based on their experience as working women fishermen. 168 
Table 5. Work Experience of Fishermen's Wife (Respondent) in Namlea Village

\begin{tabular}{cc}
\hline $\begin{array}{c}\text { Work experience } \\
\text { (year) }\end{array}$ & $\begin{array}{c}\text { Respondent } \\
\text { (Person) }\end{array}$ \\
\hline $4-8$ & 5 \\
$9-13$ & 4 \\
$>14$ & 9 \\
Total & 18 \\
\hline
\end{tabular}

Source: Primary data after processing, 2020

The number of respondents who have worked for a period of 4 - 8 years is 5 respondents, while the respondents who have worked for a period of 9-13 years are 4 respondents, and respondents who have worked in a period of $>14$ years are 9 respondents. This shows that the longer a person works, the more experience and knowledge is obtained to hone skills and expertise in the field they are engaged in overtime which fishermen's wives have.

Each fisherman household has their own goals for what they do according to their needs. In meeting household needs, the role of women as fishermen's wives in Namlea Village is very important in order to fully regulate daily household expenses based on the level of consumption needs of the number of household members. The aim of the fishermen's wife in Namlea Village in doing work is to pay for children's education and fulfill family needs and increase family income. It can be seen that every fisherman's wife wants her children to get a higher education and expects her children's life to be better than them.

The income earned by fishermen's wives and every business they do is not fully influenced by the number of working hours spent doing this work, and the various types of business that fishermen's wives do in their role of increasing household income can be seen that the income received also varies based on the work done. There are 5 fishermen's wives who work as processing fishery products (smoked fish) with an average monthly income of Rp. 694,000, while the fishermen's wives who work as unprocessed (raw) fish sellers in the market are 13 people with an average monthly income of Rp. 804,615. The most unprocessed sales of fishery products are because they have fish raw materials caught by their husbands. So that they get this profit and this income is very helpful for their household needs. 
Wilda, Samsia, Chairul, The Role of Fishermen's Wife in Increasing Family Income.

Income is any business that has been made by family members that can produce money, goods, and services so that they can be used to meet the needs of their household. Various attempts are made by the head of the family to generate income, both in the form of goods and services which later can meet household needs. The largest average income of fishermen's household is that of fishermen whose wife works as an unprocessed raw fish seller of Rp. 804,615 / month with an average household income of Rp. 2,339,231 / month. Fishermen's wife who works as a seller of fishery products in the form of raw fish is done for household needs including the cost of educating their children. The average monthly expenditure of fishermen's households is Rp. 1,000,000 -Rp. 1,550,000. These expenses are in the form of children's education costs, fulfillment of daily needs, house rent, electricity, and other expenses.

In accordance with her nature, women as housewives are responsible for household affairs, but the involvement of women in economic activities is a common phenomenon that has been going on for a long time. Facts show that when men were not women, they managed various household economic activities. Women then not only play a role in the household but also outside the household as breadwinners and are involved in social activities. In addition to solving daily household needs, he still has to devote his time to earning a living.

The fishermen's wife works as a seller of raw fish and smoked fish in the market and has 42 hours/week. The fishermen's wife carries out her work starting at 08.00 WIT to 14.00 WIT in Namlea market. The fishermen's wife works as a seller of raw fish / fresh fish and processed fish (smoked fish). But before working as a fish seller in the market, the fishermen's wife performs her duties as housewives such as cooking and if there are urgent conditions such as being late to wake up, fishermen's wives do household chores after working as fish sellers and usually children from fishermen's families participate in helping to complete work at home such as cooking, washing clothes and others.

Women's roles can be grouped into two roles, namely domestic roles, and public roles. The domestic role is the role played by women as housewives which include the necessities of life for family members at home such as washing clothes, cleaning the house, cooking, washing, taking care of children and others, Meanwhile, the public role is the role of women in helping their husbands to earn additional income, such as selling fish or processing fishery products and so on (de Oliveira CÔrtes et al., 2014).

Domestic roles are all activities carried out by fishermen's wives in maintaining fishermen's households which consist of household chores such as cooking, washing clothes, 170 
household furniture, ironing, cleaning their houses, shopping, and caring for children that cannot be measured in terms of money value (Peña-Torres et al., 2019).

The task carried out by fishermen's wives in Namlea Village to prepare food and drinks for their entire family is a fundamental task for fishermen's wives in their families In addition to serving husbands, namely preparing food and drinks for all family members, washing clothes and ironing clothes of family members apart from cooking, other household chores that are done by fishermen's wives in Namlea Village are washing dirty clothes, both their own clothes and their husband's and their children's clothes. The fishermen's wife did not do the washing of dirty clothes every day. Sometimes two or three times a day to wash clothes once. In addition, the fishermen's wife's job is to iron clothes which is done every two or three days. However, most children's school clothes, clothes that are going to be worn to the party are ironed. This household work is also an obligation for the wife in carrying out her role in the household. Cleaning the house is a place for family gatherings, besides that the house becomes a place for shelter or family protection, manages household finances, educates children, basically a wife is responsible for caring for children, educating and giving love to their children.

The role of the public is all the activities of fishermen's wives that generate income outside of their homes. Fishermen's wives are required to play a role in earning income to meet family needs. So they not only stay at home to wait for the income their husbands get from fishing, but they are also involved in earning a living.

Table 5. The role of fishermen's wife in proportion to income

\begin{tabular}{lcc}
\hline \multicolumn{1}{c}{ fisherman wife's job } & $\begin{array}{c}\text { Proportion of the Role of } \\
\text { Fishermen's Wife } \\
(\%)\end{array}$ & amount (person) \\
\hline $\begin{array}{l}\text { Processed Fish seller (smoked } \\
\text { fish) }\end{array}$ & $27-42$ & 6 \\
Raw Fish Seller & $26-50$ & 12 \\
Total & & 18 \\
\hline
\end{tabular}

Source: Primary data after processing, 2020

The work done by the fishermen's wife (respondent) in Namlea Village is selling raw fish / unprocessed fish and processed fish (smoked fish) in the Namlea market. This fisherman's wife who is in Namlea Village has a job as processing fishery products in the form of smoked fish were starting from cleaning and washing fish, then smoking is done every day when there are fish or orders from people where the smoking process takes 2-4 
Wilda, Samsia, Chairul, The Role of Fishermen's Wife in Increasing Family Income.

hours. Meanwhile, the process of selling raw fish is carried out by collecting fish and then selling it at the Namlea market around 08.00 WIT.

The proportion of fishermen's wife's income in Namlea Village to medium-sized households (27-50\%) is 18 people, which is the average proportion of the fishermen's wife's income to the household. With the following explanation, namely the proportion of income $27 \%$ for smoked fish seller fishermen's wives, 1 person for $33 \%$, for $40 \%$ as many as 2 people and $42 \%$ as much as 1 person. Meanwhile, the proportion of income for fishermen's wife who sells raw or unprocessed fish is 2 people, $27 \%$ is 1 person, 6 people are $30 \%$ $39 \%$, and $40 \%-50 \% 3$ people. When viewed based on the type of work carried out, the largest proportion of fishermen's wife's income is fishermen's wife as processing fishery products, namely $50 \%$ of total household income. This shows that fishermen's wives are able to help their husbands to increase household income.

This is in accordance with the statement in Nainggolan which states that the proportion of fishermen's wife's income can be formulated as follows with the criteria $0 \%$ $25 \%$ is the role of the wife is relatively small, $26 \%-50 \%$ is the role of the wife is classified as moderate, and $51 \%-100 \%$ is the role of the wife Classified as Large (Nainggolan et al., 2017).

Although the contribution is not too big, the economic activities of fishermen's wives in Namlea Village are felt to play quite an important role in increasing family income. This is in line with what was stated by Kabir and Huo in Widodo (2012), that the involvement of women in economic activities leads to an increase in household income.

\section{CONCLUSION}

Based on the results of the study it can be concluded that the domestic role of women which is all activities carried out by fishermen's wives (respondents) in maintaining fishermen's households in Namlea Village consists of jobs such as cooking, washing clothes, ironing, cleaning their homes, shopping and caring for children that are not measurable in value for money, while the public role of women which is all the activities of fishermen's wives that generate income outside of their homes plays a role in earning income to meet family needs. The work done by the fishermen's wife is like making smoked fish / pickled fish and selling fresh fish in the market. The income generated by the fishermen's wife (respondent) in Namlea Village from activities to increase family income contributed $26-50 \%$ to family income, where the majority of the family income generated was allocated to meet 
family needs. Although the proportion of fishermen's wife's income in Namlea Village has a moderate contribution, the involvement of fishermen's wives in increasing family income has an effect on the level of household income. The recommendations from the results of this study are as follows: a. Efforts to process fishery products provide significant additional income for families in coastal communities, but this work is still done traditionally, so it takes the role of the government or non-governmental organizations to make empowerment efforts in Namlea Village so that the business of processing fishery products is more developed; b. It is necessary to establish joint venture institutions or entities that are professionally managed to facilitate fishermen and fishery product processors so that they have access to capital and do not depend on large individual agents.

\section{REFERENCES}

Artini, L.G.S., Puspaningsih, N.L.A., 2011. Struktur Kepemilikan Dan Struktur Modal Terhadap Kebijakan Dividen Dan Nilai Perusahaan. J. Keuang. dan Perbank.

Angela Lentisco., Robert Ulric L., 2015. A Review Of Women's Access To Fish In Small-Scale

Fisheries. FAO Fisheries and Aquaculture Circular No. 1098. ISSN 2070-6065.

Arikunto., Suharsimi., 2008. Penelitian Tindakan Kelas. Bumi Aksara. Bandung .

Boediono., 2002. Pengantar Ekonomi. Erlangga, hal. 150. Jakarta.

Ciołek, D., Matczak, M., Piwowarczyk, J., Rakowski, M., Szefler, K., Zaucha, J., 2018. The perspective of Polish fishermen on maritime spatial planning. Ocean Coast. Manag.

de Oliveira CÔrtes, L.H., Zappes, C.A., Madeira Di Beneditto, A.P., 2014. Ethnoecology, gathering techniques and traditional management of the crab Ucides cordatus Linnaeus, 1763 in a mangrove forest in south-eastern Brazil. Ocean Coast. Manag.

Firdaus, M., Rahadian, R., 2016. Peran Istri Nelayan Dalam Meningkatkan Pendapatan Rumah Tangga (Studi Kasus di Desa Penjajab, Kecamatan Pemangkat, Kabupaten Sambas). J. Sos. Ekon. Kelaut. dan Perikan.

Goode., William J., 1991. Sosiologi Keluarga. Bumi Aksara. Jakarta.

Karof A Lamia., 2013. Faktor-faktor yang Mempengaruhi Tingkat Pendapatan Nelayan Kecamatan Tumpaan Kabupaten Minahasa Selatan. J. EMBA

Helmi, A., Satria, A., 2012. Fisher ' s Adaptation Strategies to Ecological Changes Abstract. Makara Hubs-Asia. 
Wilda, Samsia, Chairul, The Role of Fishermen's Wife in Increasing Family Income.

Husain, T.K., Mulyo, J.H., Jamhari, J., 2016. Analisis Perbandingan Keuntungan dan Risiko Usaha Perikanan Rakyat Sistem Monokultur dan Polikultur di Kabupaten Pangkep. Agro Ekon.

Hubeis, A.V., 2001. Gender Analysis Pathway (GAP) in Policy Outlook and Action Planning in Coperative and Small-Medium Enterprises. Bureau of Women Empowerment National Planning Board (Bappenas) RI with Expantion Employment Opportunity for Women (EEOW) Project-ILO. Jakarta.

Hutapea R., Abdul Kohar., Abdul Rosyid. 2012. Peranan Wanita Nelayan (Istri Nelayan) Jaring Insang dalam Meningkatkan Pendapatan Keluarga di Desa Bejalen Perairan Rawa Pening Kecamatan Ambarawa Kebupaten Semarang. Journal of Fisheries Resources Utilization Management and Technology Volume 1, Nomor 1, Tahun 2012, HIm 1-10.

Jane C., Ollenburger., Helen A. Moore. 2002. Sosiologi Wanita. Rineka Cipta, hal 266. Jakarta.

Kanto, S., Wisadirana, D., Chawa, A.F., Umanailo, M.C.B., 2020. Change in community work patterns. Proc. Int. Conf. Ind. Eng. Oper. Manag. 0, 2496-2502.

KPPPA, B., 2016. pembangunan ketahanan keluarga 2016, Journal of Visual Languages \& Computing.

Kusnadi., 2009. Keberadaan Nelayan dan Dinamika Ekonomi Pesisir. Yogyakarta : Ar-

RuzzMedia

Linda Waty Zen., 2009. Analisis Kontribusi Pendapatan Wanita Nelayan di Kelurahan Pasie

Nan Tigo Kecamatan Kota Tengah Kota Padang. J. Mangrove dan Pesisir IX.

Listiyandra, K., Anna, Z., Dhahiyat, Y., 2016. Kontribusi Wanita Nelayan Dalam Upaya

Pemenuhan Kebutuhan Ekonomi Keluarga Nelayan Di Muara Angke Kecamatan

Penjaringan Jakarta Utara. J. Perikan. dan Kelaut. Unpad.

Matera, J., 2014. The role of social networks in marine conservation: A case study of Providencia and Santa Catalina, Colombia. Diss. Abstr. Int. Sect. A Humanit. Soc. Sci.

Mu'adi, S., Maksum, A., Hakim, M.L., Umanailo, M.C.B., 2020. Transfer of function agricultural land. Proc. Int. Conf. Ind. Eng. Oper. Manag. 0, 2568-2574.

Mugni, A., 2006. Strategi Rumah Tangga Nelayan dalam Mengatasi Kemiskinan (Studi Kasus Nelayan Desa Limbangan, Kecamatan Juntinyuat, Kabupaten Indramayu, Propinsi Jawa Barat. [Skripsi]. Fakultas Pertanian, IPB, Bogor. 
Nainggolan, C., Suwardjo, D., Hutajulu, J., Suharyanto, Syamsuddin, S., Effendy, A., Basith, A., Yusrizal, Handri, M., Nugraha, E., Krisnafi, Y., Matheis, A., Irwansyah, Irwan, Khoerul, Novianto, D., 2017. Analyses of pole and line fishery: Catch composition and use of live bait for catching skipjack tuna Katsuwonus pelamis and yellowfin tuna Thunnus albacares in Fisheries Management Area 715, Indonesia. AACL Bioflux.

Nur Laila, N.E., Amanah, S., 2016. Strategi Nafkah Perempuan Nelayan Terhadap Pendapatan Keluarga. Sodality J. Sosiologi. Pedesaan.

Noviana Bawolye., Grace O Tambani., Victoria E N Manoppo. 2019. Peran Istri Nelayan Dalam Meningkatkan Pendapatan di Kelurahan Pasir Panjang Kecamatan Lembeh Selatan. J. Akulturasi

Payne, B., 2013. Local economic stewards: The historiography of the fishermen's role in resource conservation. Environ. Hist. Durh. N. C.

Peña-Torres, J., Dresdner, J., Quezada, F., Luzardo, I., 2019. Collective share quotas and the role of fishermen's organizations in ex-vessel price determination. Mar. Resour. Econ.

Prestes-Carneiro, G., Béarez, P., Bailon, S., Rapp Py-Daniel, A., Neves, E.G., 2016. Subsistence fishery at Hatahara (750-1230 CE), a pre-Columbian central Amazonian village. J. Archaeol. Sci. Reports.

Ritzer., George.,Douglas J. Goodman., 2008. Teori Sosiologi Modern, Jakarta: Kencana, hal 125.

Rosyidi., Suherman., 2000. Pengantar Teori Ekonomi: Pendekatan Kepada Teori Ekonomi Mikro dan Makro. PT Raja Grafindo Persada. Jakarta.

Salamah., 2005. Peranan Wanita Dalam Perekonomian Rumah Tangga Nelayan di Pantai Depok Parangtritis Bantul. Universitas PGRI Yogyakarta. J. PKS IV (14) 72-84.

Sari, A.K., Andrias, D.R., Bulak, K., Bulak, K., 2013. Faktor sosial ekonomi yang berhubungan dengan ketahanan pangan rumah tangga nelayan perkotaan di Surabaya. Media Gizi Indones.

Sasongko., Sundari S., 2009. Konsep dan Teori Gender. BKKBN. Jakarta.

Shiva Vandana., 1988. Staying alive: women, ecology and development. London: Zed Books. Soekanto, S., 2009. Peranan Sosiologi Suatu Pengantar. Jakarta: Rajawali Press. Duke Law J. 
Wilda, Samsia, Chairul, The Role of Fishermen's Wife in Increasing Family Income.

Soeyono., Dony A. Yunawan., 2013. Analisis Pendapatan Buruh Lepas Wanita Pada PT Gading Mas Indonesian Tobacco di Kabupaten Jember. Fakultas Ekonomi dan Bisnis Universitas. Jember.

Stevens, K., Frank, K.A., Kramer, D.B., 2015. Do social networks influence small-scale fishermen's enforcement of sea tenure? PLoS One.

Sukmaningrum, A., Imron, A., 2017. Memanfaatkan Usia Produktif Dengan Usaha Kreatif Industri Pembuatan Kaos Pada Remaja Di Gresik. J. Paradig.

Sumitro, S., Yuliadi, I., Kurniawansyah, E., Najamudin, N., Umanailo, M.C.B., 2020.

Reflection the concept of power foucault's. In: Proceedings of the International Conference on Industrial Engineering and Operations Management.

Sumrin, Olii, A.H., Baruadi, A.S.R., 2015. Studi Peran Perempuan Pesisir dalam Menunjang Aktivitas Perikanan di Desa Torosiaje Laut Kecamatan Popayato Kabupaten Pohuwato.

J. Ilm. Perikan. dan Kelaut.

Supranto, J., 2003. Metode Riset Aplikasinya dalam Pemasaran. Rineka Cipta. Jakarta.

Syarifah Zuraidah., Lario Saunabella, TA., 2018. Peran Istri Nelayan dalam Meningkatkan

Pendapatan Keluarga. J. Perikanan Terpadu.

Umanailo, M.C.B., 2017. Ilmu Sosial Budaya Dasar.

Wawansyah, H., Gumilar, I., Taufiqurahman, A., 2012. Kontribusi Ekonomi Produktif Wanita Nelayan Terhadap Pendapatan Keluarga Nelayan. J. Perikan. dan Kelaut.

Widodo, S., 2011. Strategi Nafkah Berkelanjutan Bagi Rumah Tangga Miskin Di Daerah Pesisir Slamet Widodo. Makara Hum. Behav. Stud. Asia.

Widodo, S., 2012. Peran perempuan dalam sistem nafkah rumah tangga nelayan. Semin. Nas. Kedaulatan Pangan dan Energi

Yuliana, L., Widiono, S., Cahyadinata, I., 2016. Strategi Nafkah Rumah Tangga Nelayan Tradisional dan Modern pada Komunitas Nelayan Sekunyit, Kaur, Provinsi Bengkulu. j. agrisep.

Zainudin, L.M., Zein, A., Idris, M.H., Luqman, W., 2019. Socio-economic profile comparison of fishermen community in Kuala Marang and Seberang Takir, Terengganu, Malaysia. J. Sustain. Sci. Manag. 